\title{
PENGARUH KECERDASAN EMOSIONAL, KOMPETENSI KARYAWAN DAN PENGALAMAN KERJA TERHADAP KINERJA KARYAWAN (STUDI PADA INDUSTRI ROTI HARUM SARI BOYOLALI)
}

\author{
Asrianingsih $^{1}$ \\ Rini Handayani ${ }^{2}$ \\ ${ }^{1,2}$ Program Studi Manajemen, STIE Atma Bhakti \\ Email : rhandayani.0574@gmail.com
}

\begin{abstract}
Increasing competition in bakery business requires companies to have a strategy in increasing human resources to increase sales volumes with good product quality. The main problem of human resource management is the factor of employee performance. There are various factors that affect employee performance including emotional intelligence, employee competence, and work experience. The purpose of this study was to analyze the significance of the influence of emotional intelligence, employee competence and work experience on the performance of Harum Sari Boyolali employees. This research uses descriptive quantitative research methods. The research sample is all 70 production employees taken by saturated sampling. The data collection method uses a questionnaire. The method of data analysis uses multiple linear regression analysis. F test results indicate that the selected regression model is fit for use (goodness of fit). The coefficient of determination (R2) obtained results of $61.8 \%$ meaning that variations in changes in employee performance can be explained by variables of emotional intelligence, employee competence and work experience and the remaining $38.2 \%$ is influenced or explained by other variables outside the research model. Hypothesis testing shows that emotional intelligence, employee competence and work experience have a significant effect on employee performance.
\end{abstract}

Keywords: Emotional Intelligence, Employee Competency, Work Experience, Employee Performance.

\section{PENDAHULUAN}

\section{Latar Belakang}

Salah satu industri yang memberi kontribusi cukup signifikan pada perkembangan industri manufaktur dan perekonomian nasional adalah industri makanan dan minuman. Kontribusi yang diberikan industri makanan dan minuman untuk produk domestrik bruto (PDB) industri non migas cukup signifikan. Berdasar data, pada triwulan I tahun 2020, sektor industri makanan dan minuman berkontribusi sebesar $36,4 \%$ terhadap PDB manufaktur. Pada 
periode yang sama, pertumbuhan sektor industri tersebut sebesar 3,9\% (Kementrian Perindustrian RI, 2020). Melihat pertumbuhan industri makanan dan minuman yang cukup baik maka perlu untuk mempertahankan kinerja pada masing-masing perusahaan tersebut sehingga eksistensinya membawa dampak positif pada PDB di Indonesia.

Kinerja perusahaan merupakan hasil atau tingkatan keberhasilan dari manajemen. Salah satu indikator yang berperan penting dalam meningkatkan kinerja perusahaan adalah kinerja karyawan. Menurut Veithzal (2010), kinerja adalah perilaku individu sebagai prestasi kerja perannya dalam perusahaan. Upaya untuk mengoptimalkan kinerja karyawan menjadi prioritas perusahaan karena peningkatan kinerja karyawan akan berdampak pada peningkatan efektivitas dan produktivitas perusahaan (Mangkunegara, 2016). Oleh sebab itu maka perlu bagi perusahaan untuk membangun berbagai faktor yang membawa pengaruh pada kinerja karyawan.

Penelitian Ardiansyah dan Sulistiyowati (2018) menyebutkan setidaknya $75 \%$ dari kesuksesan manusia tergantung pada kecerdasan emosional yang dimiliki dan kecerdasan intelektual hanya memberi pengaruh sebesar 4\%. Penelitian Ariani dan Ratnasari (2018) menyebutkan hal yang serupa bahwa kecerdasan emosi akan berpengaruh pada kesuksesan dan kehidupan seseorang. Kecerdasan emosional mampu mengendalikan kita dari berbagai macam pikiran yang berkonotasi negatif mengenai kinerja, agar hasil produksinya optimal sesuai yang diharapkan oleh pihak perusahaan. Kondisi tersebut menunjukkan kecerdasan emosional yang mampu membawa pengaruh bagi kinerja karyawan. Beberapa penelitian menunjukan bahwa kecerdasan emosional memiliki pengaruh signifikan terhadap kinerja karyawan (Mulyasari, 2018; Nurhasanah dan Sumardi,2018; Gong et al.,2019; dan Setiawan,2020). Namun penelitian Resubun et al.,(2020) memberikan hasil yang berbeda yaitu tidak adanya pengaruh antara kecerdasan emosional dengan kinerja seorang karyawan.

Tujuan strategi perusahaan tidak dapat lepas dari kinerja karyawan (yang melekat pada karyawan (Kolibacova, 2014). Pada konsep Balance Score Card (Kaplan dan Norton, 2000) menyebutkan bahwa terdapat empat perspektif yaitu keuangan, pelanggan, proses internal dan perspektif pembelajaran dan 
pertumbuhan. Dalam perspektif pembelajaran dan pertumbuhan menitikberatkan pada infrastruktur yang dibutuhkan untuk mempertahankan pertumbuhan dan peningkatan jangka panjang diantaranya adalah kemampuan dan ketrampilan sumber daya manusia yang dimiliki perusahaan. Oleh karena itu kompetensi karyawan erat kaitannya dengan kinerja yang dicapai oleh karyawan. Seorang karyawan yang memiliki kompetensi yang baik untuk mendukung pekerjaannya akan berdampak positif pada kinerjanya dalam perusahaan (Ardiansyah dan Sulistiyowati, (2018); Fadlurrahman et al.,(2021); Indiyati et al.,(2021). Namun disisi lain terdapat penelitian yang tidak menemukan adanya pengaruh antara kecerdasan emotional terhadap kinerja karyawan yaitu penelitian Suantara et al.,(2020) dan Sabil et al (2021).

Selanjutnya, kinerja karyawan dapat dipengaruhi pengalaman kerja yang dimiliki seseorang. Lengkong et al., (2019) menyatakan bahwa pengalaman kerja merupakan proses belajar dan pengembangan potensi perilaku individu. Penelitian Costanza et al.,(2012) menyebutkan bahwa karyawan yang berpengalaman akan memiliki nilai, keyakinan, serta harapan kerja yang terinternalisasi dalam pekerjaan mereka dan menghasilkan sosialisasi yang efektif dalam lingkungan kerja. Hal ini berarti bahwa dengan pengalaman kerja maka seseorang akan lebih mudah beradaptasi dengan pekerjaan atau tugas yang diembannya dan mudah berinteraksi dengan rekan sejawatnya karena adanya rasa percaya diri. Teori tersebut mendukung penelitian Husain (2018), dan Ratnawati et al.,(2020) dimana pengalaman kerja berpengaruh signifikan terhadap kinerja karyawan. Namun penelitian yang dilakukan oleh Wardayati et al.,(2019) menyebutkan bahwa pengalaman tidak memberi pengaruh pada kinerja karyawan karena pengalaman kerja belum dapat memberi ketepatan waktu dalam menyelesaikan pekerjaan dan tidak mampu menciptakan inisiatif dalam melaksanakan tugas-tugas yang baru.

Berdasarkan uraian diatas maka dengan meningkatnya kecerdasan emosional, kompetensi karyawan, dan pengalaman kerja karyawan maka diharapkan dapat membangun kinerja karyawan. Namun pada kenyataan masih ada beberapa penelitian yang menunjukkan hasil yang sebaliknya. Oleh karena itu penelitian ini akan menguji ulang peran kecerdasan emosional, kompetensi karyawan dan pengalaman kerja terhadap kinerja karyawan. 


\section{KAJIAN PUSTAKA DAN PENGEMBANGAN HIPOTESIS}

\section{Kecerdasan Emosional dan Kinerja Karyawan}

Menurut Goleman (2016), kesuksesan dalam dunia kerja dapat dicapai bukan hanya melalui cognitive intelligence saja namun emotional intelligence (EQ) juga dibutuhkan. Perusahaan membutuhkan seorang pemimpin yang memiliki $E Q$ tinggi untuk menjalankan aktivitasnya dalam lingkungan organisasi karena pemimpin akan berinteraksi dengan banyak pihak yang berada di dalam maupun di luar lingkungan kerjanya. EQ memiliki peran utama dalam membentuk moral, etika dan disiplin para karyawan. Kecerdasan emosional berkontribusi lebih besar dalam membentuk kesuksesan seseorang daripada kecerdasan intelektual karena seseorang yang memiliki ketrampilan dalam mengenali dan mengelola emosi dirinya akan lebih mudah untuk memotivasi diri sendiri, mengenali emosi orang lain, serta membina hubungan kerja sama. Seseorang yang dapat dengan baik mengontrol emosinya akan mampu menghasilkan kinerja yang lebih baik. Beberapa penelitian yang mendukung pernyataan tersebut adalah penelitian dari Mulyasari (2018), Nurhasanah dan Sumardi (2018), Gong et al., (2019) dan Setiawan, (2020) yang menyebutkan bahwa kecerdasan emosional memiliki pengaruh signifikan terhadap kinerja karyawan. Dilihat dari uraian teori yang telah dikemukakan dan hasil penelitian terdahulu, maka diajukan hipotesis pertama sebagai berikut:

$\mathrm{H}_{1}$ : Kecerdasan emosional berpengaruh signifikan terhadap kinerja karyawan

\section{Kompetensi Karyawan dan Kinerja Karyawan}

Kompetensi non akademik, kemampuan inovasi, management skill, dan kecepatan mempelajari jejaring kerja akan mampu memprediksi prestasi yang dicapai seseorang dalam pekerjaannya. Hal tersebut terjadi karena kompetensi yang memadai dan dimiliki oleh seorang karyawan akan membantu karyawan dalam memahami pekerjaannya dan mencapai prestasi kerja. Prestasi kerja dapat berupa pencapaian standar dan target perusahaan nantinya akan menunjukkan bahwa karyawan berhasil memberikan kinerja yang baik bagi pihak perusahaan (Sutrisno, 2016). Penelitian Ardiansyah dan Sulistiyowati, (2018); Fadlurrahman 
et al.,(2021); dan Indiyati et al.,(2021) menunjukkan bahwa kinerja karyawan akan meningkat dengan semakin tingginya kompetensi yang dimiliki seorang karyawan sehingga dapat diartikan bahwa kompetensi karyawan berpengaruh signifikan terhadap kinerja karyawan. Dilihat dari uraian teori yang telah disampaikan dan hasil penelitian terdahulu, maka diajukan hipotesis kedua sebagai berikut:

$\mathrm{H}_{2}$ : Kompetensi karyawan berpengaruh signifikan terhadap kinerja karyawan

\section{Pengalaman Kerja dan Kinerja Karyawan}

Berbagai macam pengalaman seseorang memberi pengaruh pada pelaksanaan tugas. sehingga pengalaman kerja seseorang akan mampu meningkatkan kemampuannya dalam menyelesaikan pekerjaannya. Jadi untuk dapat meningkatkan kinerja maka pengalaman kerja sangat dibutuhkan. Pengalaman kerja karyawan digambarkan dari tingkat penguasaan pengetahuan dan keterampilan yang dimiliki seorang karyawan dalam bekerja dapat diukur dari masa kerja dan jenis pekerjaan yang pernah dikerjakan karyawan (Husain, 2018).

Penelitian Husain (2018) dan Ratnawati et al.,(2020) mendukung teori tersebut dimana masing-masing hasil penelitian mereka memberikan bukti empiris bahwa pengalaman kerja memiliki pengaruh yang cukup signifikan pada kinerja karyawan. Semakin lama dan banyak pengalaman kerja seorang karyawan maka akan semakin baik kinerjanya. Dilihat dari uraian teoriyang dikemukakan dan hasil penelitian terdahulu, maka dapat diajukan hipotesis ketiga sebagai berikut: $\mathrm{H}_{3}$ : Pengalaman kerja berpengaruh signifikan terhadap kinerja karyawan

\section{Kerangka Pemikiran Penelitian}

Hubungan variabel independen dan variabel dependen pada penelitian ini digambarkan melalui kerangka pemikiran sebagai berikut: 
Gambar 1.

Kerangka Penelitian

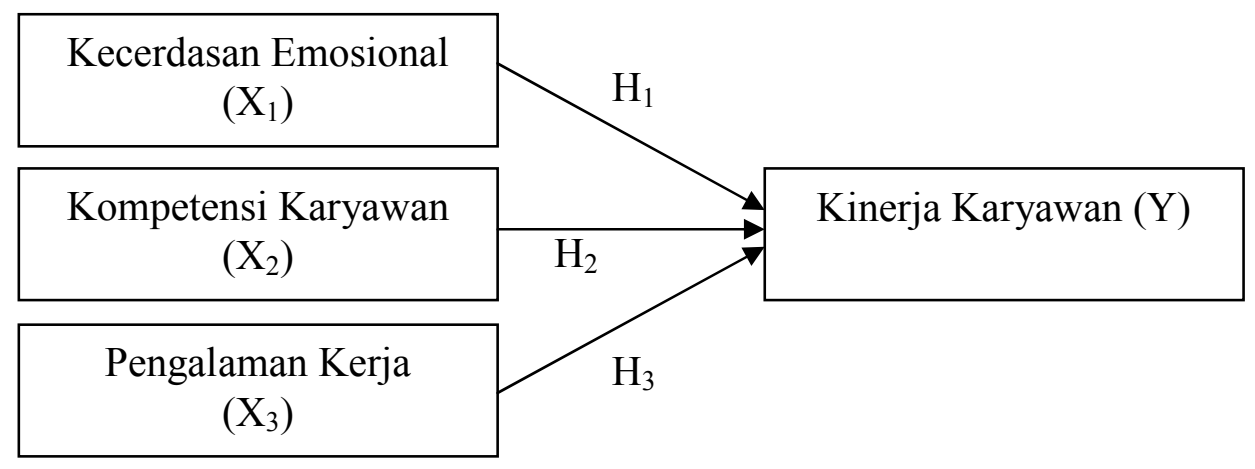

\section{METODOLOGI PENELITIAN}

\section{Jenis Penelitian}

Penelitian ini merupakan penelitian dengan pendekatan deskriptif kuantitatif yaitu penelitian yang analisisnya lebih fokus pada data-data numerial (angka) dan diolah dengan menggunakan metode statistika yang digunakan untuk menggambarkan variabel penelitian (Sugiyono, 2017).

\section{Populasi dan Sampel Penelitian}

Populasi penelitian terdiri dari seluruh karyawan industry roti Harum Sari Boyolali sebanyak 70 orang. Metode pengambilan sampel menggunakan total sampel atau sampling jenuh dimana seluruh anggota populasi merupakan sampel penelitian yaitu sebanyak 70 orang karyawan.

\section{Metode Pengumpulan Data}

Sumber data penelitian adalah data primer. Data primer yaitu data yang diperoleh secara langsung dari responden dengan menggunakan kuesioner. Pengumpulan data dengan kuesioner yang disebarkan kepada responden yang dijadikan sampel penelitian. 


\section{Definisi Operasional dan Pengukuran Variabel}

Pengukuran variabel penelitian ini dengan menggunakan pengukuran skala likert yang terdiri dari 5 skala yaitu dari skala sangat tidak setuju (1) sampai dengan sangat setuju (5). Adapun definisi dan indikator masing-masing variabel adalah sebagai berikut:

1. Kecerdasan emosional merupakan kemampuan untuk mengontrol diri, memacu, tetap tekun, serta dapat memotivasi diri sendiri, dimana kecakapan tersebut mencakup pengelolaan untuk emosi baik yang positif maupun negatif (Goleman, 2016). Goleman (2016) membagi kecerdasan emosional ke dalam lima dasar kecerdasan emosional yang dijadikan indikator dalam penelitian ini yaitu: kesadaran diri, pengaturan diri, motivasi, empati, dan keterampilan sosial.

2. Kompetensi karyawan adalah kemampuan seseorang dalam melaksanakan tugasnya sesuai dengan ilmu pengetahuan, keterampilan, teknologi dan pengalaman yang relevan dengan bidang tugasnya sehingga berdampak pada pengembangan motivasi kerja dan kinerja. Indikator kompetensi karyawan yang digunakan diadopsi dari Nurhasanah dan Sumardi (2018) yaitu pengetahuan, kemampuan, keterampilan, pengalaman, motivasi, kemampuan karyawan mengatasi isu-isu emosional, dan kapasitas intelektual karyawan dalam menyelesaikan pekerjaannya.

3. Pengalaman kerja merupakan pengetahuan yang diperoleh selama karyawan bekerja pada perusahaan ditempat mereka bekerja. Indikator pengalaman kerja yang digunakan diadopsi dari Likdanawati (2018) yaitu lama waktu atau masa kerja, tingkat pengetahuan dan keterampilan, penguasaan pada pekerjaan dan peralatan, bekerja dengan tenang dan dapat menduga timbulnya kesulitan.

4. Kinerja karyawan adalah kuantitas atau kualitas sesuatu yang dihasilkan atau jasa yang diberikan oleh seseorang yang melakukan pekerjaan. Indikator kompetensi karyawan yang digunakan diadopsi dari Ruky (2013) dan Dharma (2014) yaitu kuantitas, kualitas, ketepatan waktu, penggunaan waktu dalam kerja, kemampuan bekerja sama, kedisiplinan, dan komitmen kerja. 


\section{Metode Analisis Data}

Suatu data sebelum digunakan untuk menguji hipotesis penelitian maka perlu dilakukan beberapa pengujian yaitu analisis kualitas data, pengujian asumsi klasik dan pengujian kesesuaian model. Analisis kualitas data dilakukan dengan pengujian validitas yaitu korelasi Product Moment dan pengujian reliabilitas yang diukur dengan alat ukur cronbach alpha. Pengujian asumsi klasik meliputi uji normalitas, uji multikolinieritas, dan uji heteroskedastisitas. Pengujian normalitas menggunakan kolmogorov smirnov test. Pengujian multikolinieritas dapat melihat nilai tolerance dan variance inflation factor (VIF) dimana diharapkan nilai VIF < 10 dan nilai tolerance $>0,1$. Pengujian heteroskedastisitas dilakukan dengan scatter plot dimana diharapkan titik-titik menyebar tidak membentuk suatu pola tertentu yang menandakan bahwa tidak terjadi gejala heteroskedastisitas. Adapun Pengujian kesesuaian model dilakukan dengan uji $\mathrm{F}$ dan koefisien determinasi $\left(\mathrm{R}^{2}\right)$. Adapun untuk pengujian hipotesis dapat dilakukan dengan mengunakan uji t.

\section{HASIL DAN PEMBAHASAN}

\section{Karakteristik Responden}

Responden sebanyak 70 orang terdiri dari 49 responden (70\%) adalah lakilaki dan selebihnya sejumlah 21 repsonden (30\%) adalah wanita. Dilihat dari usia diketahui mayoritas responden berusia 20-30 tahun sebanyak 48 responden $(68,6 \%)$ dikarenakan perusahaan Harus Sari Boyolali lebih banyak merekrut karyawan yang masih muda sehingga masih memiliki tingkat produktif yang baik. Karakteristik responden berdasarkan tingkat pendidikan dapat diketahui mayoritas responden berpendidikan SMA sebanyak 62 responden $(88,6 \%)$. Adapun dari masa bekerja diketahui mayoritas responden telah bekerja selama 1-5 tahun sebanyak 44 responden $(62,9 \%)$.

\section{Pengujian Kualitas Data}

Pada pengujian validitas nilai $\mathrm{r}_{\text {tabel }}$ diperoleh dari menghitung nilai $\mathrm{df}=\mathrm{n}-$ 2 , sehingga $\mathrm{df}=70-2=68$ didapatkan nilai $\mathrm{r}_{\text {tabel }}=0,235$. Adapun seluruh nilai $\mathrm{r}_{\text {hitung }}$ pada masing-masing item pertanyaan menunjukkan nilai lebih besar dari 
nilai $r_{\text {tabel }}$ sehingga dapat disimpulkan bahwa item-item pertanyaan yang akan digunakan untuk analisis hipotesis dinyatakan valid.

Reliabilitas suatu variabel dilihat dari nilai cronbach alphanya yang harus lebih besar dari 0,7. Pada tabel 3, analisis data menunjukkan bahwa setiap variabel dinyatakan reliabel. Hal ini terbukti dari hasil pengujian reliabilitas dengan SPSS menunjukkan nilai cronbach alpha $>0,7$.

Tabel 1.

Hasil Uji Reliabilitas

\begin{tabular}{|l|c|c|c|}
\hline \multicolumn{1}{|c|}{ Variabel } & Koefisien Alpha & Sig & Keterangan \\
\hline Kecerdasan Emosional & 0,789 & 0,7 & Reliabel \\
\hline Kompetensi Karyawan & 0,775 & 0,7 & Reliabel \\
\hline Pengalaman Kerja & 0,800 & 0,7 & Reliabel \\
\hline Kinerja Karyawan & 0,723 & 0,7 & Reliabel \\
\hline
\end{tabular}

Sumber : Data primer diolah, 2020

\section{Pengujian Asumsi Klasik}

Pengujian multikolinieritas pada masing-masing variabel menunjukkan nilai VIF lebih kecil dari 10 dan nilai tolerance lebih besar dari 0,1 (tabel 2). Hal ini menunjukkan dalam model penelitian tidak ditemukannya adanya multikolinieritas.

Tabel 2.

Hasil Uji Multikolinieritas

\begin{tabular}{|l|c|c|l|}
\hline \multicolumn{1}{|c|}{ Variabel } & Tolerance & VIF & \multicolumn{1}{c|}{ Keterangan } \\
\hline Kecerdasan Emosional & 0,699 & 1,431 & Bebas Gejala Multikolinieritas \\
\hline Kompetensi Karyawan & 0,570 & 1,756 & Bebas Gejala Multikolinieritas \\
\hline Pengalaman Kerja & 0,631 & 1,584 & Bebas Gejala Multikolinieritas \\
\hline
\end{tabular}

Sumber : Data primer diolah, 2020

Pengujian normalitas menyatakan bahwa keseluruhan data penelitian memiliki sebaran yang terdistribusi dengan normal, hal ini dikarenakan nilai signifikansi sebesar $0,140>0,05$. Pengujian heteroskedastisitas yang ditunjukkan oleh gambar 1 nampak bahwa tidak ada pola yang jelas, serta titik-titik menyebar di atas dan di bawah angka 0 pada sumbu Y, maka tidak terjadi heteroskedastisitas dalam model regresi dan memenuhi syarat analisis regresi linier. 
Gambar 1

Grafik Scatter Plot Uji Heteroskedastisitas

Scatterplot

Dependent Variable: $K K$

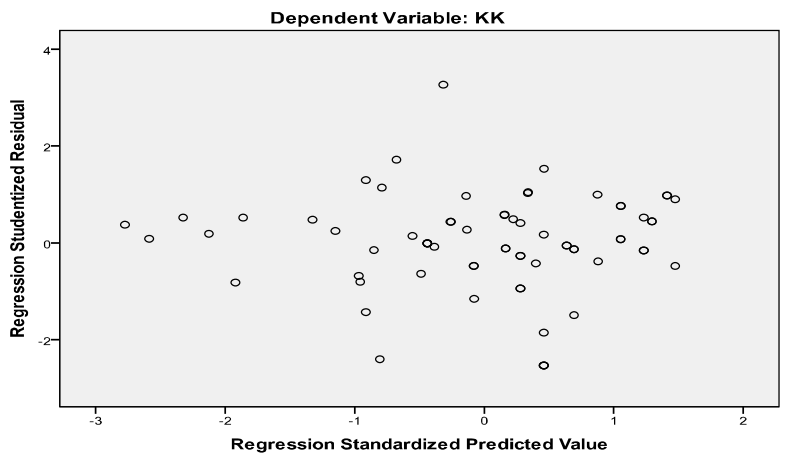

\section{Pengujian Kesesuaian Model}

Hasil analisis regresi linier berganda pada data yang ada ditunjukkan pada tabel 3 sebagai berikut ini :

Tabel 3.

Hasil Analisis Regresi Linier Berganda

\begin{tabular}{|l|c|c|c|c|}
\hline \multicolumn{1}{|c|}{ Variabel } & B & Std. Error & $\mathbf{t}_{\text {hitung }}$ & Sig. \\
\hline Konstanta & 2,562 & & & \\
\hline Kecerdasan Emosional & 0,225 & 0,105 & 2,150 & 0,035 \\
\hline Kompetensi Karyawan & 0,344 & 0,088 & 3,889 & 0,000 \\
\hline Pengalaman Kerja & 0,348 & 0,086 & 4,023 & 0,000 \\
\hline
\end{tabular}

Sumber : Data primer diolah, 2020

Hasil pengujian analisis regresi linier berganda pada tabel 3 membentuk persamaan regresi sebagai berikut:

$$
\begin{aligned}
\text { Kinerja Karyawan }= & 2,562+0,225 \text { Kecerdasan Emosional }+0,344 \\
& \text { Kompetensi Karyawan }+0,348 \text { Pengalaman } \\
& \text { Kerja }+ \text { Error Term }
\end{aligned}
$$

Persamaan regresi dapat diinterpretasikan sebagai berikut:

1. Konstanta sebesar 2,562 artinya jika tidak ada nilai kecerdasan emosional, kompetensi karyawan, dan pengalaman kerja maka kinerja karyawan sebesar 2,562 .

2. Koefisien regresi kecerdasan emosional sebesar 0,225 berarti bahwa meningkatnya satu poin kecerdasan emosional maka akan meningkatkan kinerja karyawan sebesar 0,225 (dengan asumsi variabel kompetensi karyawan dan pengalaman kerja dianggap nol).

3. Koefisien regresi kompetensi karyawan sebesar 0,344 berarti bahwa meningkatnya satu poin kompetensi karyawan maka akan meningkatkan 
kinerja karyawan sebesar 0,344 (dengan asumsi variabel kecerdasan emosional dan pengalaman kerja dianggap nol).

4. Koefisien regresi pengalaman kerja karyawan sebesar 0,348 berarti bahwa meningkatnya satu poin pengalaman kerja maka akan meningkatkan kinerja karyawan sebesar 0,348 (dengan asumsi variabel kecerdasan emosional dan kompetensi karyawan dianggap nol).

\section{Uji Kelayakan Model}

Hasil pengujian $\mathrm{F}$ menyatakan bahwa nilai $\mathrm{F}_{\text {hitung }}$ sebesar $38,250>\mathrm{F}_{\text {tabel }}$ pada $n=70$ dan alpha $=0,05$ yaitu 2,74 . Hal ini berarti model regresi yang dipilih layak digunakan (goodness of fit) untuk pengujian hipotesis. Nilai koefisien determinasi $\left(\mathrm{R}^{2}\right)$ sebesar 0,618 . Hal tersebut berarti bahwa kecerdasan emosional, kompetensi karyawan, dan pengalaman kerja secara simultan memberi kontribusi akan variasi kinerja karyawan sebesar 61,8\% sedangkan sisanya 38,2\% dijelaskan oleh variabel lain diluar model penelitian yang ada.

\section{Pengujian Hipotesis dan Pembahasan}

Analisis regresi linier berganda dilakukan untuk mengukur sejauh mana pengaruh kecerdasan emosional, kompetensi karyawan, dan pengalaman kerja terhadap kinerja karyawan perusahaan Harum Sari Boyolali. Hasil pengujian t dapat dilihat pada tabel 3 .

Hasil uji t (tabel 3) menunjukkan bahwa kecerdasan emosional memiliki nilai $t_{\text {hitung }}(2,150)>t_{\text {tabel }}(1,997)$ dengan nilai signifikansi sebesar $0,035<0,05$. Hal ini berarti bahwa $\mathrm{H}_{1}$ diterima yaitu kecerdasan emosional berpengaruh signifikan terhadap kinerja karyawan Harum Sari Boyolali. Nilai koefisien regresi variabel kecerdasan emosional bernilai positif ini dapat diartikan bahwa semakin tinggi kecerdasan emosional yang dimiliki karyawan Harum Sari Boyolali maka semakin meningkatkan kinerjanya, demikian pula sebaliknya. Kecerdasan emosional yang baik dalam diri karyawan akan membuat karyawan mencapai kinerja yang lebih baik karena karyawan akan memiliki kesadaran diri, empati, pengaturan diri, dan motivasi yang tentu saja dapat menunjang dalam menyelesaikan tugasnya. Setiap individu tentunya memiliki kesadaran akan emosi yang melekat dalam dirinya dan individu akan berperilaku sesuai dengan 
pengetahuannya atas kecerdasan emosional yang dimilikinya, hal ini berperan dalam menentukan kesuksesan dan prestasi kerja (Hartanto et al, 2017). Hasil penelitian ini konsisten dengan penelitian dari Mulyasari, (2018); Nurhasanah dan Sumardi, (2018); Gong et al., (2019); dan Setiawan, (2020) yang menyatakan bahwa kecerdasan emosional berpengaruh signifikan terhadap kinerja karyawan.

Nilai kompetensi karyawan pada table 3 menunjukkan nilai $t_{\text {hitung }}(3,889)>$ $\mathrm{t}_{\text {tabel }}(1,997)$ dengan nilai signifikansi sebesar $0,000<0,05$. Hal ini berarti $\mathrm{H}_{2}$ diterima yaitu kompetensi karyawan berpengaruh signifikan terhadap kinerja karyawan Harum Sari Boyolali. Nilai koefisien regresi kompetensi karyawan bernilai positif diartikan bahwa semakin tinggi kompetensi yang dimiliki karyawan Harum Sari Boyolali maka semakin meningkatkan kinerjanya, demikian pula sebaliknya. Karyawan dengan kompetensi tinggi memiliki keterampilan maupun pengetahuan yang tinggi serta sikap kerja yang baik untuk melaksanakan pekerjaannya dengan baik. Dengan kata lain karyawan dengan kompetensi yang tinggi akan mampu mencapai hasil yang baik dari pekerjaan yang dilaksanakannya. Hasil penelitian ini konsisten dengan hasil penelitian dari Ardiansyah dan Sulistiyowati, (2018); Fadlurrahman et al.,(2021); dan Indiyati et al.,(2021) yang menyatakan bahwa kompetensi karyawan berpengaruh signifikan terhadap kinerja karyawan.

Nilai pengalaman kerja pada table 3 memperoleh nilai $t_{\text {hitung }}(4,023)>t_{\text {tabel }}$ $(1,997)$ dengan nilai signifikansi sebesar $0,000<0,05$. Hal ini berarti $\mathrm{H}_{3}$ diterima artinya pengalaman kerja berpengaruh signifikan terhadap kinerja karyawan Harum Sari Boyolali. Nilai koefisien regresi pengalaman kerja bernilai positif ini dapat diartikan bahwa semakin banyak pengalaman kerja yang dimiliki karyawan Harum Sari Boyolali maka semakin meningkatkan kinerjanya, demikian pula sebaliknya. Semakin banyak pengalaman kerja karyawan, maka semakin terampil dalam melakukan pekerjaan dan semakin baik cara berpikir dan bersikap untuk mencapai tujuan yang perusahaan. Karyawan yang berpengalaman dapat bekerja lebih baik karena mereka memiliki dasar pengetahuan yang lebih mendalam dan lebih mahir mengorganisir pengetahuan mereka. Keunggulan tersebut bermanfaat bagi pengembangan keahlian. Teori tersebut sesuai dengan pendapat Zahro et al (2018) mengemukakan bahwa pengalaman kerja merupakan bekal utama seorang 
karyawan untuk menekuni bidang pekerjaan tertentu, terutama bagi perusahaan yang mengutamakan bakat atau kemampuan tertentu dari seorang karyawan. Hal ini dikarenakan orang yang berpengalaman dalam bekerja akan melakukan pekerjaan yang sama secara berulang-ulang sehingga dapat belajar dari berbagai kesalahan yang pernah dilakukan dan membantu karyawan lebih menguasai pekerjaan sehingga dapat meningkatkan kinerja yang dimiliki. Hasil penelitian ini konsisten dengan hasil penelitian dari Husain (2018) dan Ratnawati et al.,(2020) yang menyatakan bahwa pengalaman kerja berpengaruh signifikan terhadap kinerja karyawan.

\section{KESIMPULAN}

Berdasarkan hasil analisis dan pembahasan mengenai pengaruh kecerdasan emosional, kompetensi karyawan dan pengalaman kerja terhadap kinerja karyawan Harum Sari Boyolali, maka dapat disimpulkan bahwa kecerdasan emosional berpengaruh signifikan terhadap kinerja karyawan Harum Sari Boyolali. Apabila kecerdasan emosional yang dimiliki karyawan Harum Sari Boyolali baik maka kinerja karyawan juga akan meningkat.

Kompetensi karyawan berpengaruh signifikan terhadap kinerja karyawan Harum Sari Boyolali. Apabila kompetensi pada karyawan Harum Sari Boyolali baik maka kinerja karyawan juga akan baik, dan sebaliknya apabila kompetensi yang dimiliki karyawan Harum Sari Boyolali rendah maka kinerja karyawan juga akan kurang baik. Peningkatan kompetensi karyawan dapat dilakukan dengan cara melakukan training di bidang-bidang tertentu dan mengadakan sistem rolling pada tiap bagian untuk jangka waktu per 6 bulan sekali.

Pengalaman kerja berpengaruh terhadap kinerja karyawan Harum Sari Boyolali. Apabila pengalaman kerja yang dimiliki karyawan Harum Sari Boyolali banyak maka kinerja karyawan juga akan meningkat, dan sebaliknya apabila pengalaman kerja yang dimiliki karyawan Harum Sari Boyolali sedikit maka kinerja karyawan juga akan menurun. Dalam membangun pengalaman kerja karyawan untuk posisi tertentu harus merekrut karyawan yang sudah berpengalaman saja. Apabila karyawan tersebut kurang berpengalaman maka 
dalam posisi tertentu tersebut dapat merekrut karyawan yang berkompeten dibidangnya.

\section{DAFTAR PUSTAKA}

Ardiansyah, Yusuf., dan Sulistyowati, Lisa Hary. 2018. Pengaruh Kompetensi dan Kecerdasan Emosional Terhadap Kinerja Pegawai. Jurnal Inspirasi Bisnis dan Manajemen Vol 2, (1), 91-100.

Ariani, M., dan Ratnasari, D, 2018. Effect Of Emotional Intelligence Against Employee Performance In Department Of Labor And Social. Journal of Business \& Finance in Emerging Markets

Costanza, D, P., Badger, J, M., Fraser, R, L., Severt, J. B., and Gade, P. A. 2012. Generational diff erences in work-related attitudes: A meta-analysis. Journal of Business and Psychology, 27(4), 375-394.

Dharma, Agus. 2014. Manajemen Supervisi. Jakarta: Raja Grafindo Persada.

Fadlurrahman, M.F., Amelia, T.C., and Pratminingsih, S.A. 2021. The Influence of Workload and Competence on Employee Performance. Psychology and Educational Journal, Vol. 58, No.3, DOI: https://doi.org/10.17762/pae.v58i3.2762

Goleman, Daniel. 2016. Emotional Intelligence: Mengapa EL Lebih Penting Daripada IQ. Cetakan Ke-21 Alih bahasa T. Hermaya. Jakarta: PT. Gramedia.

Gong, Z., Chen, Y., and Wang, Y., 2019, The Influence of Emotional Intelligence on Job Burnout and Job Performance: Mediating Effect of Psychological Capital, Frontiers Psychology., 10 Desember 2019, DOI: doi.org/10.3389/fpsyg.2019.02707

Hartanto, Siti Hidayah dan Harnoto. 2017. Peningkatan Kinerja Pegawai melalui Kecerdasan Emosional, Kecerdasan Spiritual, dan Kepuasan Kerja Pegawai di Kecamatan Gunungpati Kota Semarang. Jurnal Ekonomi Manajemen dan Akuntansi No. 43 / Th. XXIV / Oktober 2017, 76-88.

Hasyim. 2018. Effect of Work Experience and Work Placement on Employee Performance in Companies PT. Hadji Kalla at Makassar. PAM Journal, Vol. 2 Issue 2, October 2018: 101-116.

Indiyati, D., Ghina, A., and Romadhona, A. F. 2021. Human Resource Competencies, Organizational Culture, and Employee Performance. International Journal of Science and Society, 3(1), 1-10. DOI : https://doi.org/10.200609/ijsoc.v2i4.251.

Kaplan, Robert S. dan David P. Norton. 2000. "Balanced Scorecard: Menerapkan strategi menjadi aksi", Erlangga, Jakarta.

Kolibáčová, Gabriela. 2014. The Relationship Between Competency and Performance. Acta Universitatis Agriculturae et Silviculturae Mendelianae Brunensis. 62. 1315-1327. 10.11118/actaun201462061315.

Lengkong, F., Lengkong, V. P., dan Taroreh, R. N. 2019. Pengaruh Keterampilan, Pengalaman dan Lingkungan Kerja terhadap Kinerja Karyawan di PT. Tri Mustika Cocominaesa (Minahasa Selatan). Jurnal 
EMBA: Jurnal Riset Ekonomi, Manajemen, Bisnis dan Akuntansi, Vol.7, No.1.

Likdanawati. 2018. Pengaruh Pengalaman Kerja, Kompetensi dan Disiplin Kerja Terhadap Kinerja Pegawai di Rumah Sakit Umum Labuhan Haji Tengah Aceh Selatan. Jurnal Visioner \& Strategis Volume 7, Nomor 1, Maret 2018: 17-22.

Mangkunegara, A.A. Anwar Prabu. 2016. Manajemen Sumber Daya Manusia. Perusahaan. Bandung: PT. Remaja Rosdakarya.

Mulyasari, Irma. 2018. Pengaruh Kecerdasan Emosional Dan Kompetensi Terhadap Kinerja Pegawai. Journal of Management Review Volume 2 Number 2 Page (190-197).

Nurhasanah, Siti dan Rebin Sumardi. 2018. Pengaruh Kecerdasan Emosional, Kompetensi dan Kompensasi Finansial terhadap Kinerja Karyawan PT Agranet Multicitra Siberkom (Detikcom). Jurnal Ilmu Manajemen Oikonomia Volume 14, No. 2, Juli 2018: 26-42.

Ratnawati, E., Sukidjo., dan Efendi, R. 2020. The Effect of Work Motivation and Work Experience on Employee Performance, International Journal of Multicultural and Multireligious Understanding, Vol. 7, No. 8. DOI: http://dx.doi.org/10.18415/ijmmu.v7i8.1809.

Resubun, R.M., Bachri,A.A., and Dahniar. 2020. Effect Of Intellectual Intelligence, Emotional Intelligence, And Work Discipline On Employee Performance (A Study On Employee PT. Amanahanugerah Adi Mulia Banjarmasin), Jurnal Wawasan Manajemen, Vol. 8 No.2.

Ruky, Achmad S. 2013. Sistem Manajemen Kinerja, Cetakan Ketiga. Jakarta: PT. Gramedia Pustaka Utama.

Sabil., Suhartono., Winarno, S.H., Putra, O.P., Widod, D.P. 2021. The Effect of Work Environment, Competence, and Motivation on Employee's Performance in Electronic Companies in the Industrial District of Bekasi Regency, Perspektif Vol. 19, No.1. DOI : https://doi.org/10.31294/jp.v19i1.9584

Setiawan, N., Maisyarah, R., dan Haraha, R. 2020. Analysis Of Emotional Intelligence And Work Discipline On Employee Performance With Organizational Commitment As An Intervening Variable, Airlangga Journal Of Innovation Management, Vol 1, No.2. DOI : doi.org/10.20473/ajim.v1i2.21906

Suantara, I.K., Sitiari, N.W., and Yasa, P.N.S. 2020. The Role of Organizational Commitments Mediates The Effect of Competence on Employee Performance in PT. Bali Tangi Spa Production, Jurnal Ekonomi dan

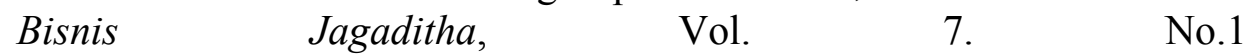
DOI: https://doi.org/10.22225/jj.7.1.1653.53-64.

Sugiyono. 2017. Metode Penelitian Kuantitatif, Kualitatif, dan R\&D. Bandung: Alfabeta.

Sutrisno, Edy. 2016. Manajemen Sumber Daya Manusia. Jakarta: Kencana Prenada Media Group.

Wardayati, S.M., Miqdad, M., Efendi, H.I., dan Arisandy F.N. 2019. Performance improvement through internal control, experience and individual rank. Journal of Contemporary Accounting, Vol. 1, No.2, 107-119. DOI $: 10.20885 /$ jca.vol1.iss2.art4. 
Pengaruh Kecerdasan Emosional .......................Asrianingsih, Rini Handayani

Zahro, Hana Maskhufatuz, Bambang Suyadi, dan Sutrisno Djaja. 2018. Pengaruh Pengalaman Kerja dan Curahan Jam Kerja terhadap Kinerja Karyawan (Studi Kasus Pada Home Industry Tas Pita Plastik Bapak Almunir di Desa Setail Kecamatan Genteng Kabupaten Banyuwangi Tahun 2017). Jurnal Pendidikan Ekonomi: Jurnal Ilmiah Ilmu Pendidikan, Ilmu Ekonomi, dan Ilmu Sosial Volume 12 Nomor 1 (2018), 8-14. 